\title{
Article \\ Understanding the Decisive Causes of PPP Project Disputes in China
}

\author{
Xiaoxiao Zheng*(D), Yisheng Liu, Ruijiao Sun, Jinzhao Tian and Qi Yu
}

check for updates

Citation: Zheng, X.; Liu, Y.; Sun, R.; Tian, J.; Yu, Q. Understanding the Decisive Causes of PPP Project Disputes in China. Buildings 2021, 11, 646. https://doi.org/10.3390/ buildings11120646

Academic Editor: Carlos Oliveira Cruz

Received: 5 November 2021

Accepted: 9 December 2021

Published: 13 December 2021

Publisher's Note: MDPI stays neutral with regard to jurisdictional claims in published maps and institutional affiliations.

Copyright: (c) 2021 by the authors. Licensee MDPI, Basel, Switzerland. This article is an open access article distributed under the terms and conditions of the Creative Commons Attribution (CC BY) license (https:// creativecommons.org/licenses/by/ $4.0 /)$.
School of Economics and Management, Beijing Jiaotong University, Beijing 100044, China; yshliu1@bjtu.edu.cn (Y.L.); srj165@sina.com (R.S.); rickytian@bjtu.edu.cn (J.T.); 13931301182@163.com (Q.Y.)

* Correspondence: xxzhengbucea@163.com

\begin{abstract}
Disputes are inevitable in public-private partnership (PPP) projects and generate great losses of time and money in practice. If an in-depth understanding of dispute sources can be obtained beforehand, the process of PPP may become more smooth. This paper aims to identify and assess the causes of PPP disputes between the public and private sectors. First, 15 causes are explored based on the PPP litigation cases from China Judgments Online. Second, the Decision-Making Trial and Evaluation Laboratory (DEMATEL) method is utilized to provide a holistic understanding of the relative importance and define the cause-effect categories among PPP dispute sources. The results demonstrate that the top three decisive causes of PPP disputes are the repudiation of contracts (result category), lack of expertise and experience (reason category), and unreasonable risk allocation (result category). Further, dispute avoiding strategies are proposed to minimize or completely avoid the occurrence of PPP disputes. The outputs are expected to add meaningful insights to potential sources of dispute and dispute prevention mechanisms in PPPs. To some extent, the investors can develop strategic measures through the findings before entering into PPP markets.
\end{abstract}

Keywords: public-private partnership; disputes; causes; decision-making trial and evaluation laboratory (DEMATEL); case study

\section{Introduction}

Public-private partnerships (PPPs) are a globally used type of financing, which brings multiple benefits for both government and public society. The involvement of the private operator relieves the government's budgetary burden and improves public service quality due to their advanced technology and management experience [1-3]. After the 2007-2008 global financial crises, the adoption of PPP policy appeals to governments in almost all countries [4]. For instance, PPP or private finance initiatives (PFIs) are now being seen as a new form of risk allocation in public infrastructure projects in the UK [5]. In Australia, as opposed to the original goal of obtaining private investment, the choice of PPP procurement is mainly to achieve value for money, appropriate risk transfer, design innovation, etc., [6]. China has unique political, economic, cultural, and legal characteristics [7]. Before the 1980s, a highly centralized socialist economic system was adopted in China [8]. Infrastructure investment and construction was the sole responsibility of the government [6]. Since the reform and opening-up policy implemented in China after the 1980s, there has been a great demand for capital in Chinese infrastructure development. The government's funds alone cannot meet the large investment needs for infrastructure construction. The investment system of infrastructure must be reformed. Thus, PPP was introduced in China to fill the financing gap. Unlike western countries, China is more conservative in procuring projects. Due to the lack of advanced technology and management in the Chinese construction industry [9], as well as the absence of a mature PPP management system (e.g., the lack of a national PPP law) [10], PPP practice in China has received much attention from scholars in recent years. 
The information published by the China Public-Private Partnerships Center (CPPPC) indicated that in October 2021, 10103 PPP projects have been implemented nationwide with a total investment of 15.8 trillion RMB [11]. With the introduction and rapid development of PPPs in China, considering the complexity of this financing model, numerous problems have also emerged in Chinese PPP practice. The focus of this study is placed on the dispute between the public authority and the private partner, which is considered pivotal for causing distress and failure of the PPP projects [12,13]. Compared with traditional construction projects, PPP projects are more prone to disputes [14]. This is because of the long-term contract durations, complicated processes, multiple stakeholders with myriad interests and objectives, and high levels of uncertainty $[15,16]$. As published by China Judgments Online, during the period from 2013 to 2020, more than 1000 cases related to PPP projects were resolved through courts in China [17]. Nonetheless, the number of lawsuits continues to rise yearly [18].

The demand for infrastructure is now higher than ever, the successful implementation of China's PPP projects is important to attract private investment and promote the sustainable development of the PPP financing model. Against this backdrop, it is necessary to conduct a comprehensive and in-depth investigation of the causes of PPP disputes so that both the public authority and private partner will obtain a holistic understanding of the potential dispute sources in the implementation of PPP projects beforehand. Essentially, this will help to avoid or minimize the occurrence of disputes, which can lead to huge loss of time and money.

To reach the objective, this paper identified the causes of PPP disputes through litigation cases from China Judgments Online (an official website that publishes judgment documents of courts at all levels nationwide), which was validated through expert interviews. Moreover, the Decision-Making Trial and Evaluation Laboratory (DEMATEL) method was used to assess the importance of each cause and the interdependencies of these causes. Finally, counterstrategies based on the decisive causes were explored to minimize the frequency of PPP disputes to some extent. The DEMATEL method is considered one of the most effective tools for investigating the importance and causality among elements of the system [19]. DEMATEL was chosen because of its ability to determine the interdependencies of elements in the system, meanwhile, the interrelationships among elements can be directly visualized through the cause-effect diagram [19].

This study is organized as follows. First, the literature review is discussed. Next, a total of 14 litigation cases from China Judgments Online is adopted to identify the dispute causes in the research methodology section. Meanwhile, the specific steps of the DEMATEL approach are introduced. Then the results and discussions of DEMATEL are presented. Finally, recommendations to minimize dispute occurrence based on the findings are prompted.

\section{Literature Review}

Considering the complexity of construction projects, the construction industry is increasingly turning to resolve disputes through the judicial system [20]. Nevertheless, there are two obvious disadvantages to addressing disputes through litigation. On the one hand, the litigation process often leads to long time costs [21]. Due to the complexity of PPP projects, dispute settlement becomes more difficult. According to the court documents published by China Judgments Online, the duration may last 1 to 5 years from acceptance to trial of the PPP lawsuits [18]. On the other hand, the prolonged, detailed investigation makes litigation costs very high [22]. It is expensive to hire a team of professional lawyers who specialize in the PPP field. What are the main root causes of PPP disputes? How to avoid PPP disputes, and even avoid them entering into the litigation process? This study aims to find answers to these questions. 


\subsection{Potential Dispute Causes in PPPs}

Various failures and unforeseen risks are inevitable in PPP projects due to the longterm agreement and high levels of uncertainty [18]. Both the government and the private partners attempt to resolve the problem through renegotiations or other rational manners rather than immediately embroil in disputes. If the contradiction is not properly handled and solved, then disputes may occur. A considerable number of PPP disputes will destroy the private partner's investment confidence and generate great losses, which is harmful to the sustainable development of PPPs [23].

Therefore, this study is closely related to two aspects of research. On the one hand, the risks and how to allocate in PPP agreements were the focus of past studies. Numerous researchers identified a variety of risks, such as political risk, legal risk, exchange and revenue risks, demand risk, environmental risk, and operational risk [24-29]. Ke et al. [26] conducted a detailed comparative study to illustrate the risk allocation preference among mainland China, Hong Kong Special Administrative Region, UK and Greece.

On the other hand, the prior literature mentioned factors influencing failure, renegotiation, and early termination of PPP projects. Chan et al. [30] put forward the potential obstacles to conducting PPP projects in mainland China and Hong Kong Special Administrative Region and the results showed that the top three obstacles were lengthy delays in negotiation, inadequate experience and skills, and lengthy delays because of political debate. Then the critical success factors for implementing PPP projects from Chinese perspective were also investigated [31]. These factors were classified into five decisive factors: stable macroeconomic environment, shared responsibility, competitive procurement process, stable political and social environment, and judicious government control. Cruz and Marques [32,33] extracted the exogenous and endogenous determinants that lead to PPP project renegotiations in Portugal. The findings concluded that demand below forecast, delays in expropriation, force majeure, etc., were the main exogenous causes for renegotiations, whereas the risk-sharing agreement, contract clauses, and key performance indicators (KPIs) were the key endogenous factors for renegotiations. Through the case study method, Song et al. [34] identified several factors influencing early termination and divided them into four categories: government default factors, private sector default factors, joint default factors, and nondefault factors.

\subsection{Use of DEMATEL Methodology}

The DEMATEL technique was first developed by the Geneva Research Centre of the Battelle Memorial Institute to illustrate the causal relationships among various elements and determine the importance of each element in the system [35,36]. It is a comprehensive method using causal relationship matrices or digraphs to establish a structural model and portray cause-effect relationships between systems components [37]. Although other evaluation techniques, such as interpretative structural modeling (ISM) or the analytical hierarchy process (AHP), may also be used, the DEMATEL approach has its obvious advantages [38]. First, this method allows for broader discrimination for measures of evaluation (ISM only has 0-1 levels) and multiple directional relationships (AHP has a unidirectional relationship and multiple separate matrices requiring integration). Further, without the need for large amounts of data, the DEMATEL approach can reveal the interrelationships between various criteria in social science problems [39]. According to Chileshe et al. [40], small data in qualitative research can still be performed to generalize meaningful findings because the study value is based on the quality rather than the quantity of data.

This method has been used successful in quantifying interactions among research factors in various domains, including construction management. Hiete et al. [41] indicated the interrelationships between the criteria of building rating systems in terms of sustainability. To improve the performance of suppliers in carbon management, Hsu et al. [42] recognized the influential criteria of carbon management in the green supply chain through the DEMATEL approach. Costa et al. [43] used the DEMATEL technique to provide a new understanding of the barriers to improve the customer-supplier relationship in construc- 
tion supply chains by showing cause-effect relationships among these barriers. Dwijendra et al. [44] identified the most important and influential social impacts of high-rise buildings during the post-occupancy phase using the DEMATEL method.

In practice, PPP dispute is not caused by a sole reason but a combination of multiple reasons. By using the DEMATEL method, the public authority and the private sector can acquire a holistic understanding of the relative importance and relationships among PPP dispute causes. Then the key causes should be addressed to facilitate the sustainable development of PPP projects. Thus, DEMATEL is more suitable for analyzing and identifying the decisive causes of PPP disputes.

\subsection{Knowledge Gap}

A significant amount of studies have made great efforts on the causes of construction disputes [45-49]. Nevertheless, these studies and findings have mainly focused on the traditional bid-build projects, few studies have been conducted to investigate the causes of disputes between public and private sectors in PPPs. Moreover, the studies about the failure of PPP projects mainly identified the factors or risks that trigger renegotiation or early termination in PPP projects. However, these risks or factors cannot be straightforwardly treated as equal to the sources of PPP project disputes. Considering the rapid development of PPP in China, the potential sources of PPP disputes are still unclear, which brings great resistance to the implementation of PPPs. In addition, PPP dispute avoiding mechanisms have also caught little attention in existing literature.

To fill these knowledge gaps, this paper intends to explore the causes of PPP disputes using litigation cases from China. Furthermore, the root causes are identified using the DEMATEL method to obtain the appropriate dispute prevention measures. Essentially, the findings of this paper will contribute to providing effective information for potential Chinese or international investors to ensure their successful practices in PPP projects. Furthermore, the research results will set a solid foundation for the hypothesis formulation of the empirical studies of PPP disputes in the future.

\section{Research Methodology}

The aim of this paper is devoted to identifying the causes of PPP disputes between public authorities and private partners based on the multi-case study method. Then the DEMATEL model is developed to analyze the interrelationships among all causes and evaluate their importance. Furthermore, disputes prevention strategies are proposed based on the decisive causes. which can be helpful to minimize the possibility of disputes occurrence. The methodology is presented in Figure 1.

\subsection{Identification of Dispute Causes Based on Cases}

\subsubsection{Case Study}

The case study method is an effective tool in many disciplines. It has been widely used in the domain of identifying significant factors impacting the key issues of the PPP pattern. For instance, Chen [50] identified the factors impacting the re-applicability of a pilot Build Operate Transfer (BOT) project towards future projects based on the experience from Chengdu No. 6 Water Plant B Project. Martins et al. [51] used the PPP projects of wind power plants to illustrate the application of a PPP mode in Portugal. Cruz and Marques [32] investigated the exogenous determinants for PPP renegotiations in Portugal on a real database of 87 concessions. Song et al. [34] identified the factors influencing early termination of PPP projects based on case studies, and Zheng et al. [18] analyzed the litigation cases to extract the main events that trigger PPP project disputes in China. Almost all the scholars indicated that case study is an effective method to support this research. 


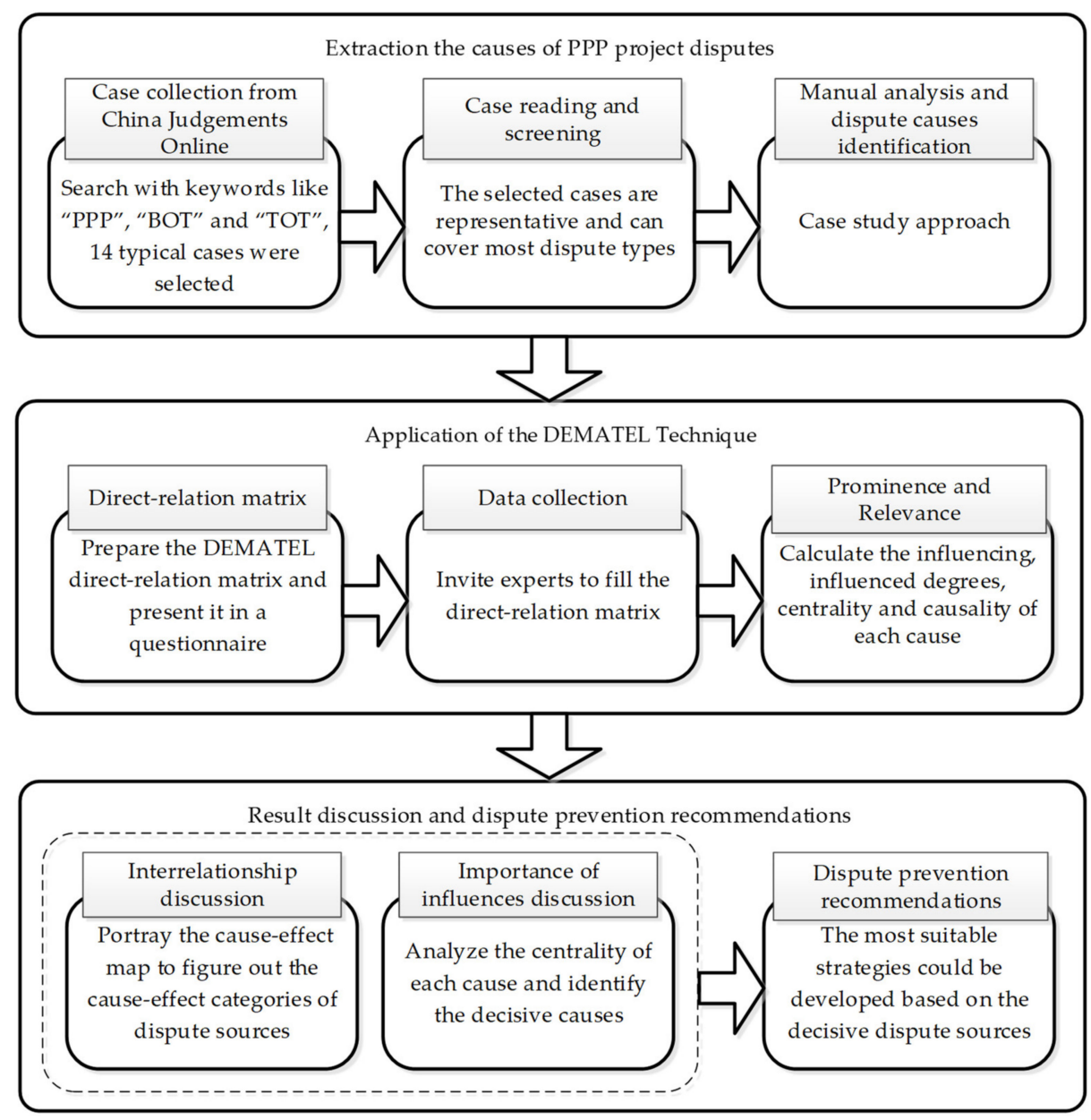

Figure 1. Research methodology.

\subsubsection{Case Selection}

Litigation is the extreme manifestation of the dispute between the two parties, and can best reflect the core characteristics of the dispute. Therefore, the PPP lawsuits from China Judgments Online were selected for this research.

The criteria for selecting cases are as follows: (1) the plaintiff and defendant in the litigation are the public and private sector, excluding financing institution, contractor, material supplier, etc.; (2) the selected cases are not in the appeals process and the judge's decision is final, which ensures the real situation and root causes of disputes can be accurately analyzed and identified from the cases; (3) the types of cases are comprehensive and involve sewage treatment, gas supply, water supply, transportation, etc. In this regard, a total of 14 litigation cases (as shown in Table 1) were selected to identify the dispute causes.

\subsubsection{Identification of PPP Dispute Causes}

To reveal the vital events and causes behind the disputes, elements such as the facts of cases, PPP contract terms, the focus of controversy, and the court judgment have been deeply analyzed. To better explain the logic, the extraction process is presented in Table 1. Table 1 contains the disputes' basic information (column 3), the court judgment made by judges (column 4), direct dispute events (column 5), and dispute causes behind the dispute events (column 6). Furthermore, the expert review was carried out to seek professional cognizance (the interview was conducted simultaneously with expert scoring in Section 3.3). The theme of the expert review is to eliminate the inappropriate causes and supplement important causes based on the identified causes. As a result, 15 causes that triggered PPP disputes between public authorities and private partners were extracted. Table 2 summarizes these 15 causes and introduces their description. 
Table 1. Process used to identify causes for PPP disputes.

\begin{tabular}{|c|c|c|c|c|c|}
\hline No. & Project & Case Information & Court Judgment & Dispute Events & Dispute Causes \\
\hline 1 & Huoshaoping Water Plant & $\begin{array}{l}\text { (1) The water demand developed too } \\
\text { fast, the waterwork could not meet } \\
\text { residents' needs. Then the government } \\
\text { terminated the contract and prepared } \\
\text { the buyback of the project. } \\
\text { (2) The clauses for conditions, } \\
\text { procedures, and compensation of } \\
\text { abrogation of the PPP contract were } \\
\text { not stipulated specifically in the } \\
\text { contract. Therefore, the two parties did } \\
\text { not reach an agreement on the } \\
\text { compensations for investment and } \\
\text { liquidated damages. }\end{array}$ & $\begin{array}{l}\text { To protect the public interest, the } \\
\text { government terminated the contract to } \\
\text { prepare a new waterwork, which } \\
\text { should not be considered as a breach of } \\
\text { the covenant. Hence the liquidated } \\
\text { damages were excluded from the } \\
\text { compensations. }\end{array}$ & $\begin{array}{l}\text { (1) Change in market } \\
\text { demand; } \\
\text { (2) Nationalization; } \\
\text { (3) Poorly defined } \\
\text { responsibilities. }\end{array}$ & $\begin{array}{l}\text { (1) Unexpected changes; } \\
\text { (2) Incomplete contract. }\end{array}$ \\
\hline 2 & $\begin{array}{l}\text { Changsha Economic and } \\
\text { Technological Development } \\
\text { Zone Municipal Road }\end{array}$ & $\begin{array}{l}\text { (1) The public sector did not finish the } \\
\text { land expropriation work on a } \\
\text { prespecified date, which caused the } \\
\text { suspension of the project. } \\
\text { (2) The private sector asked repeatedly } \\
\text { for solutions; however, the problems } \\
\text { remained unsolved. }\end{array}$ & $\begin{array}{l}\text { (1) The public sector failed to comply } \\
\text { with its obligation to deliver the } \\
\text { necessary land to the private sector in } \\
\text { due time. } \\
\text { (2) The private sector's claim for } \\
\text { remedies (i.e., land replacement for the } \\
\text { project) was supported by the court. }\end{array}$ & $\begin{array}{l}\text { (1) Inadequate compensation } \\
\text { to displaced persons; } \\
\text { (2) Delays in expropriation; } \\
\text { (3) Administrative } \\
\text { nonfeasance. }\end{array}$ & $\begin{array}{l}\text { (1) Inadequate investigation } \\
\text { and preparation; } \\
\text { (2) Repudiation of contract. }\end{array}$ \\
\hline 3 & $\begin{array}{l}\text { Zaozhuang Gas Concession } \\
\text { Project }\end{array}$ & $\begin{array}{l}\text { (1) To prevent monopoly, the } \\
\text { government granted the third-party } \\
\text { concession of gas in the same area. } \\
\text { (2) The construction of the competitive } \\
\text { project would trigger a serious impact } \\
\text { on the gas usage of the previous } \\
\text { project. }\end{array}$ & $\begin{array}{l}\text { The newly constructed project was a } \\
\text { violation of the contract. The } \\
\text { administrative conduct should be } \\
\text { revoked according to law. } \\
\text { Nevertheless, to protect the public } \\
\text { interest, as per clause } 74 \text { of the } \\
\text { "People's Republic of China (PRC) } \\
\text { Administrative Procedure Law", the } \\
\text { court decided that the competitive } \\
\text { project remained although it was } \\
\text { illegal. Accordingly, the government } \\
\text { was supposed to pay subsidies to the } \\
\text { original private sector. }\end{array}$ & $\begin{array}{l}\text { (1) Government constructed } \\
\text { competitive project; } \\
\text { (2) Absence of spirit of } \\
\text { contract. }\end{array}$ & Repudiation of contract \\
\hline
\end{tabular}


Table 1. Cont.

\begin{tabular}{|c|c|c|c|c|c|}
\hline No. & Project & Case Information & Court Judgment & Dispute Events & Dispute Causes \\
\hline 4 & $\begin{array}{l}\text { Jiangsu Business } \\
\text { Administration Management } \\
\text { Information System (MIS) }\end{array}$ & $\begin{array}{l}\text { (1) For the sake of network security, the } \\
\text { professional CA system did not receive } \\
\text { government approval, which led to the } \\
\text { early termination of the PPP project. } \\
\text { (2) The significant disagreements } \\
\text { between the public and private sectors } \\
\text { were whether the failure of the public } \\
\text { sector to achieve official permission } \\
\text { constituted a breach of the contract } \\
\text { and how to bear the losses. }\end{array}$ & $\begin{array}{l}\text { (1) First, the approval result was out of } \\
\text { the public sector's control. Second, } \\
\text { there were no explicit stipulations in } \\
\text { the contract about who is responsible } \\
\text { for the consequences. Hence, the } \\
\text { Jiangsu government did not constitute } \\
\text { a breach of the PPP contract. } \\
\text { (2) Due to the absence of clauses about } \\
\text { the distribution of obligations after } \\
\text { contract termination, both parties } \\
\text { should bear losses. }\end{array}$ & $\begin{array}{l}\text { (1) Without government } \\
\text { approval; } \\
\text { (2) Poorly defined } \\
\text { responsibilities. }\end{array}$ & $\begin{array}{l}\text { (1) Unreliable feasibility } \\
\text { studies; } \\
\text { (2) Incomplete contract; } \\
\text { (3) Lack of expertise and } \\
\text { experience. }\end{array}$ \\
\hline 5 & $\begin{array}{l}\text { Fujian Wujinyuan Sewage } \\
\text { Treatment Plant }\end{array}$ & $\begin{array}{l}\text { (1) The actual sewage supply was } \\
\text { much lower than the forecast. } \\
\text { (2) The minimum sewage supply } \\
\text { guarantee was not stipulated in the } \\
\text { contract; therefore, the government } \\
\text { rejected subsidy or price/period } \\
\text { adjustment. } \\
\text { (3) The private sector stopped } \\
\text { operating the sewage treatment } \\
\text { facilities, causing leakage of sewage. }\end{array}$ & $\begin{array}{l}\text { (1) The government did not promise } \\
\text { subsidies in the contract, which means } \\
\text { that the demand risk was taken solely } \\
\text { by the private partner. } \\
\text { (2) Because of the environmental } \\
\text { pollution caused by the private sector, } \\
\text { the government's claim to terminate } \\
\text { the contract was supported. }\end{array}$ & $\begin{array}{l}\text { (1) Demand was } \\
\text { overestimated; } \\
\text { (2) Unfair demand risk } \\
\text { design; } \\
\text { (3) Illegal act of private sector. }\end{array}$ & $\begin{array}{l}\text { (1) Unreliable feasibility } \\
\text { studies; } \\
\text { (2) Inaccurate demand } \\
\text { forecast; } \\
\text { (3) Unreasonable risk } \\
\text { allocation; } \\
\text { (4) Improper operation; } \\
\text { (5) Absence of proper } \\
\text { communication. }\end{array}$ \\
\hline 6 & $\begin{array}{l}\text { Hetian Gas Concession } \\
\text { Project }\end{array}$ & $\begin{array}{l}\text { (1) Some users defaulted to pay gas } \\
\text { usage fees to the private sector. } \\
\text { (2) The private sector shut off gas } \\
\text { supplies to customers who were often } \\
\text { in arrears with their gas bills. } \\
\text { (3) The government canceled the } \\
\text { concession because of the abuse of } \\
\text { power by the private sector. }\end{array}$ & $\begin{array}{l}\text { (1) The suspension of gas supplies was } \\
\text { due to the users' payment default. } \\
\text { Consequently, it was illegal for the } \\
\text { government to terminate the contract } \\
\text { and take over the project. } \\
\text { (2) Nevertheless, to protect the public } \\
\text { interest, as per clause } 74 \text { of the "PRC } \\
\text { Administrative Procedure Law", the } \\
\text { court decided that the government was } \\
\text { still in charge of the project. } \\
\text { Accordingly, the government was } \\
\text { supposed to provide remedies. }\end{array}$ & $\begin{array}{l}\text { (1) Users defaulted on fees; } \\
\text { (2) Public service was } \\
\text { suspended; } \\
\text { (3) Concession was retracted. }\end{array}$ & $\begin{array}{l}\text { (1) Users' payment default; } \\
\text { (2) Improper operation; } \\
\text { (3) Absence of proper } \\
\text { communication. }\end{array}$ \\
\hline
\end{tabular}


Table 1. Cont.

\begin{tabular}{|c|c|c|c|c|c|}
\hline No. & Project & Case Information & Court Judgment & Dispute Events & Dispute Causes \\
\hline 7 & $\begin{array}{l}\text { Mianyang } \\
\text { Underground Space } \\
\text { Development Project }\end{array}$ & $\begin{array}{l}\text { (1) The project required the demolition } \\
\text { of two old footbridges, which have } \\
\text { high historical and cultural value. In } \\
\text { this regard, the deputies of the Local } \\
\text { People's Congress proposed to cancel } \\
\text { the project. } \\
\text { (2) The public sector demanded to } \\
\text { terminate the contract. Conversely, the } \\
\text { private sector believed that the } \\
\text { government shall not be entitled to } \\
\text { terminate the contract. }\end{array}$ & $\begin{array}{l}\text { The public opposition was an } \\
\text { unexpected event and the primary } \\
\text { cause which prevented the } \\
\text { construction of the project. Neither } \\
\text { party was at fault, therefore, the } \\
\text { government was entitled to terminate } \\
\text { the contract. }\end{array}$ & $\begin{array}{l}\text { (1) Improper site selection; } \\
\text { (2) Public opposition. }\end{array}$ & $\begin{array}{l}\text { (1) Inadequate investigation } \\
\text { and preparation; } \\
\text { (2) Public opposition. }\end{array}$ \\
\hline 8 & $\begin{array}{l}\text { Neijiang } 207 \text { Provincial } \\
\text { Highway }\end{array}$ & $\begin{array}{l}\text { (1) State Council of the PRC enacted } \\
\text { new regulations to cancel Class II } \\
\text { highway tolls. } \\
\text { (2) The government decided to redeem } \\
\text { the project. Because the calculation of } \\
\text { reasonable investment rewards was } \\
\text { not stipulated in the contract, the two } \\
\text { parties did not reach an agreement on } \\
\text { the issue of reasonable investment } \\
\text { rewards. }\end{array}$ & $\begin{array}{l}\text { (1) The government should pay the } \\
\text { return of investment and } \\
\text { compensation for investment interest } \\
\text { to the private sector. } \\
\text { (2) The court decided that the } \\
\text { government should pay the private } \\
\text { sector for expected revenues at the } \\
\text { annual rate of return of } 15 \% \text { by } \\
\text { referring to the average return rates of } \\
\text { similar projects in China. }\end{array}$ & $\begin{array}{l}\text { (1) Class II highway tolls } \\
\text { canceled; } \\
\text { (2) Nationalization; } \\
\text { (3) Absence of important } \\
\text { clauses. }\end{array}$ & $\begin{array}{l}\text { (1) Unexpected changes; } \\
\text { (2) Lack of expertise and } \\
\text { experience; } \\
\text { (3) Incomplete contract. }\end{array}$ \\
\hline 9 & $\begin{array}{l}\text { Yichang } \\
\text { Waste-to-Energy Power Plant }\end{array}$ & $\begin{array}{l}\text { (1) The progress of project } \\
\text { environmental impact assessment was } \\
\text { affected by public opposition. } \\
\text { (2) To win the understanding of the } \\
\text { villagers, the private sector spent a lot } \\
\text { of time on science advocacy, which } \\
\text { resulted in exceeding the deadline for } \\
\text { government approval required by the } \\
\text { Provincial Development and Reform } \\
\text { Commission. }\end{array}$ & $\begin{array}{l}\text { (1) The contract stipulated that the } \\
\text { private partner shall be responsible for } \\
\text { all the approval procedures of the } \\
\text { project, including the environmental } \\
\text { impact assessment report and official } \\
\text { permission. } \\
\text { (2) The private sector failed to fulfill its } \\
\text { obligations; therefore, the government } \\
\text { had the legal right to request the } \\
\text { termination of the contract. }\end{array}$ & $\begin{array}{l}\text { (1) Public opposition; } \\
\text { (2) Without government } \\
\text { approvals for PPP contracts. }\end{array}$ & $\begin{array}{l}\text { (1) Public opposition; } \\
\text { (2) Unreasonable risk } \\
\text { allocation. }\end{array}$ \\
\hline
\end{tabular}


Table 1. Cont.

\begin{tabular}{|c|c|c|c|c|c|}
\hline No. & Project & Case Information & Court Judgment & Dispute Events & Dispute Causes \\
\hline 10 & $\begin{array}{l}\text { Dengfeng Ludian Sewage } \\
\text { Treatment and Reclaimed } \\
\text { Water Recycling Plant }\end{array}$ & $\begin{array}{l}\text { (1) The public and private sectors } \\
\text { signed the contract without bidding } \\
\text { procedures. } \\
\text { (2) There is a drinking water source } \\
\text { located downstream of the proposed } \\
\text { site. Meanwhile, the quantity of } \\
\text { recycled water could not be } \\
\text { guaranteed. Therefore, the } \\
\text { government could not deliver the land } \\
\text { to the private sector. } \\
\text { (3) The government rejected the } \\
\text { responsibilities, citing the invalid } \\
\text { contract. }\end{array}$ & $\begin{array}{l}\text { (1) As per clause } 3 \text { of the "PRC Tenders } \\
\text { and Bids Law", PPP projects must be } \\
\text { awarded through a public bidding } \\
\text { process. Otherwise, the contract shall } \\
\text { be invalid and have no legal effect. } \\
\text { (2) For the resources put into the } \\
\text { project, the public and private sectors } \\
\text { should bear corresponding losses } \\
\text { according to their faults (without } \\
\text { tendering and bidding process). }\end{array}$ & $\begin{array}{l}\text { (1) Irregular tendering and } \\
\text { bidding process; } \\
\text { (2) Improper site selection; } \\
\text { (3) Unfeasible } \\
\text { implementation plan. }\end{array}$ & $\begin{array}{l}\text { (1) Lack of expertise and } \\
\text { experience; } \\
\text { (2) Inadequate investigation } \\
\text { and preparation; } \\
\text { (3) Unreliable feasibility } \\
\text { studies. }\end{array}$ \\
\hline 11 & $\begin{array}{l}\text { Guangzhou Zengcheng } \\
\text { Sports Park }\end{array}$ & $\begin{array}{l}\text { (1) Due to the time-consuming } \\
\text { tendering and bidding procedures, the } \\
\text { selected site was converted into prime } \\
\text { farmland. } \\
\text { (2) In China, prime farmland cannot be } \\
\text { used for development. Thus, the } \\
\text { government could not deliver the land } \\
\text { to the private sector. }\end{array}$ & $\begin{array}{l}\text { The claim of the private sector to } \\
\text { terminate the contract was supported. } \\
\text { The government should compensate } \\
\text { for the losses of early-phase } \\
\text { investment. }\end{array}$ & Land acquisition failed & $\begin{array}{l}\text { Delay in decision-makings by } \\
\text { government }\end{array}$ \\
\hline 12 & Weilu Expressway & $\begin{array}{l}\text { (1) The concession was granted } \\
\text { without tendering and bidding } \\
\text { procedures. } \\
\text { (2) The government introduced new } \\
\text { regulations to prohibit the public } \\
\text { sectors from providing financing } \\
\text { assurance for private parties. } \\
\text { (3) The private sector did not have } \\
\text { sufficient capital to construct the } \\
\text { project. }\end{array}$ & $\begin{array}{l}\text { (1) As per clause } 3 \text { of the "PRC Tenders } \\
\text { and Bids Law", PPP projects must be } \\
\text { awarded through a public tender } \\
\text { process. Otherwise, the contract shall } \\
\text { be invalid. } \\
\text { (2) The government paid the private } \\
\text { sector based on the actual cost of the } \\
\text { project. }\end{array}$ & $\begin{array}{l}\text { (1) Irregular tendering and } \\
\text { bidding process; } \\
\text { (2) Shortage of funds; } \\
\text { (3) Change in law. }\end{array}$ & $\begin{array}{l}\text { (1) Lack of expertise and } \\
\text { experience; } \\
\text { (2) Insufficient financing } \\
\text { capacity; } \\
\text { (3) Unreasonable risk } \\
\text { allocation; } \\
\text { (4) Unexpected changes. }\end{array}$ \\
\hline
\end{tabular}


Table 1. Cont.

\begin{tabular}{|c|c|c|c|c|c|}
\hline No. & Project & Case Information & Court Judgment & Dispute Events & Dispute Causes \\
\hline 13 & $\begin{array}{l}\text { Nanjing Liuhe Sewage } \\
\text { Treatment Plant }\end{array}$ & $\begin{array}{l}\text { (1) The actual volume of sewage } \\
\text { treatment was much lower than the } \\
\text { contract promissory. } \\
\text { (2) According to the contract, the } \\
\text { government was supposed to pay } \\
\text { sewage treatment fees based on } 2000 \\
\text { m3 when the daily average volume is } \\
\text { equal to or less than } 2000 \mathrm{~m} 3 \text {. } \\
\text { (3) The government did not pay the } \\
\text { sewage treatment fees, and the arrears } \\
\text { amounted to nearly } 10 \text { million RMB. }\end{array}$ & $\begin{array}{l}\text { (1) The government should pay the } \\
\text { sewage treatment fee following its } \\
\text { contractual commitment. } \\
\text { (2) The government should pay the } \\
\text { arrears and liquidated damages for } \\
\text { deferred payment. }\end{array}$ & $\begin{array}{l}\text { (1) Demand was } \\
\text { overestimated; } \\
\text { (2) Government defaulted on } \\
\text { sewage treatment fee; } \\
\text { (3) Government defaulted on } \\
\text { minimum revenue guarantee } \\
\text { (MRG). }\end{array}$ & $\begin{array}{l}\text { (1) Unreliable feasibility } \\
\text { studies; } \\
\text { (2) Inaccurate demand } \\
\text { forecast; } \\
\text { (3) Repudiation of contract; } \\
\text { (4) Poor financial } \\
\text { affordability. }\end{array}$ \\
\hline 14 & $\begin{array}{l}\text { Jinsuo Industrial Park } \\
\text { Sewage Treatment Plant }\end{array}$ & $\begin{array}{l}\text { Due to the uncompleted sewage pipe } \\
\text { network by the government, the } \\
\text { sewage treatment plant could not be } \\
\text { put into operation. }\end{array}$ & $\begin{array}{l}\text { The two parties reached an agreement } \\
\text { that the arbitration commission took } \\
\text { full responsibility for the possible } \\
\text { disputes. Therefore, the jurisdiction of } \\
\text { the court would be excluded. }\end{array}$ & $\begin{array}{l}\text { (1) Lack of supportive } \\
\text { infrastructure; } \\
\text { (2) Administrative } \\
\text { nonfeasance. }\end{array}$ & $\begin{array}{l}\text { (1) Repudiation of contract; } \\
\text { (2) Absence of proper } \\
\text { communication. }\end{array}$ \\
\hline
\end{tabular}

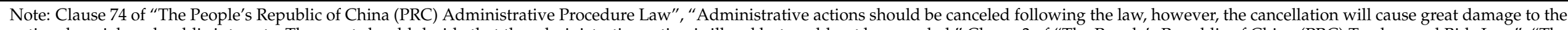

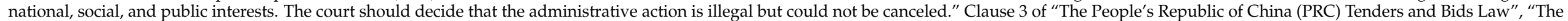

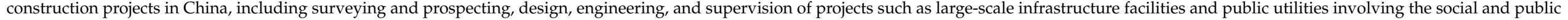
interests and public safety, must be subject to tenders." 
Table 2. The causes of PPP disputes and description.

\begin{tabular}{|c|c|c|}
\hline Symbol & Dispute Causes & Description \\
\hline $\mathrm{C} 1$ & Public opposition & $\begin{array}{l}\text { Public opposition refers to political and even public opposition to } \\
\text { project construction or operation due to reasons that the public } \\
\text { interests are threatened. For example, the noise of the highways will } \\
\text { disturb the nearby residents, which may be opposed by the public. }\end{array}$ \\
\hline $\mathrm{C} 2$ & Lack of expertise and experience & $\begin{array}{l}\text { The implementation of PPP contracts requires professional talents } \\
\text { with financing, design, construction, operation, and transfer } \\
\text { knowledge. The lack of expertise and experience in PPPs, especially } \\
\text { local authorities, often leads to improper understanding of their } \\
\text { duties and obligations, thus resulting in many problems including } \\
\text { disputes. }\end{array}$ \\
\hline
\end{tabular}

An incomplete contract has gaps, missing provisions, or ambiguities.

C3 Incomplete contract

The incomplete contract results from bounded rationality, information asymmetry, and transaction cost. Consequently, when there is a contingency, a consensus cannot be reached due to the absence of specific provisions in the PPP contract, which will result in aggravation of the contradiction.

C4 Unreasonable risk allocation

Delay in decision-makings by the government

C6

Unreliable feasibility studies

C7 Insufficient financing capacity

C8

Improper operation

C9

Unexpected changes
To maintain a long-term partnership, the risks and benefits need to be shared fairly. The misallocation or inappropriate transferring of risks often result in breach of contracts and potential distress of PPP projects. For example, leaving project approval or license responsibilities solely to the private sector may lead to delays in completion or a failure to obtain the project permit.

Delay in decision-makings usually originates from poor-quality decisionmakers, inefficient decision-making processes, absence of liability accounting mechanisms, no reliable guidelines for decision-making, and so on. Lengthy delays in critical decisions-makings contribute to the failure of obtaining official approval and finishing land acquisition. These events will result in conflicts and disputes.

The feasibility studies are a crucial basis of government decision-making. Only if the analysis at the outset demonstrates that the project is economically, technically, and environmentally feasible, can it be developed as a PPP and proceed to procurement. Unreliable feasibility studies will lead to the failure of PPP projects, and more importantly, it sours the relations between public and private partners.

In addition to the private sector's original capital, the loans from financial institutions are the main sources of funds for PPP projects. The private sector's financial position, the profitability of the PPP project, and the macroeconomic environment are the critical factors that the financial institutions need to examine. Insufficient financing capacity often results from the above factors.

The private sector is very aggressive towards the breach of contract by the government, which often leads to environmental pollution, public security violations, and other illegal behaviors.

Unexpected changes include law and regulatory changes, tariff changes, market demand changes, nationalization, etc. These changes at the national or regional level may affect project financing, market price, or project tolls and may even lead to the termination of PPP projects. 
Table 2. Cont.

\begin{tabular}{|c|c|c|}
\hline Symbol & Dispute Causes & Description \\
\hline C10 & Absence of proper communication & $\begin{array}{l}\text { The various problems and different changes are inevitable in PPP } \\
\text { projects due to the long-term agreement. If there is no proper } \\
\text { communication in this process to understand the problems and map } \\
\text { out timely strategies, it is likely to lead to disputes. }\end{array}$ \\
\hline $\mathrm{C} 11$ & Poor financial affordability & $\begin{array}{l}\text { Financial affordability refers to the public sector's ability to afford the } \\
\text { necessary payments. Because the government payments for any PPP } \\
\text { projects are required when providing relevant supporting facilities, } \\
\text { government subsidies, repurchase, or compensation. Insufficient } \\
\text { affordability will arise problems such as default. }\end{array}$ \\
\hline $\mathrm{C} 12$ & Users' payment default & $\begin{array}{l}\text { The unwillingness of users to pay for the services, poor service } \\
\text { quality, etc., could cause users to refuse or delay paying fees. Users' } \\
\text { payment default decreases the interests of the private sector or even } \\
\text { disrupts the revenue streams which will cause operating costs to } \\
\text { overrun during the operation stage. Thus, if the private sector does } \\
\text { not cope with it properly, it will leave the government to terminate } \\
\text { the contract. }\end{array}$ \\
\hline $\mathrm{C} 13$ & Inadequate investigation and preparation & $\begin{array}{l}\text { On the one hand, in the preparatory stage of the project, the } \\
\text { governments do not conduct a diligent investigation of site selection, } \\
\text { market prices, compensation to displaced persons, etc. On the other } \\
\text { hand, no contingency plans or measures are formed by both sides to } \\
\text { help deal with possible contingencies. }\end{array}$ \\
\hline $\mathrm{C} 14$ & Repudiation of contract & $\begin{array}{l}\text { A clear indication of the unwillingness or inability to perform the } \\
\text { contract. An intention of one party to be no longer bound by the } \\
\text { contract will also constitute repudiation. }\end{array}$ \\
\hline C15 & Inaccurate demand forecast & $\begin{array}{l}\text { The literature about contract theory presents the idea that a longer } \\
\text { duration of PPP contracts tends to arise disputes more often because } \\
\text { of the difficulties of demand estimation in the long run. In practice, if } \\
\text { projects' revenue streams are exclusively or largely based on market } \\
\text { demand, inaccurate demand forecasts (particularly realized demand } \\
\text { lower than assumed) will have a significant impact on projects' } \\
\text { return and profitability. }\end{array}$ \\
\hline
\end{tabular}

\subsection{DEMATEL Technique}

The DEMATEL method is an effective tool to explore the essential features of problems, which will be helpful to support managers to make decisions and generate countermeasures to solve certain problems [52]. The specific steps of the DEMATEL approach are introduced as follows:

Step 1: Generation of original average matrix

First of all, the binary influencing relations and the relations' strength among elements in the system need to be investigated. In this study, the degree of direct influence of dispute cause $C_{i}$ on $C_{j}$ is represented by $C_{i j}$, which is divided into five levels with the scores of 4,3 , 2,1 , and 0 , namely, "strong influence", "relatively strong influence", "moderate influence", "weak influence", and "no influence", respectively. The direct influence degree among different PPP dispute causes is obtained by asking experts to assign scores in accordance with their expertise and PPP project experience. Then the original average matrix $C$ is found by averaging all the experts' scores. The matrix can be expressed as Equation (1):

$$
\mathrm{C}=\left[\begin{array}{cccc}
0 & \mathrm{C}_{12} & \cdots & \mathrm{C}_{1 \mathrm{n}} \\
\mathrm{C}_{21} & 0 & \cdots & \mathrm{C}_{2 \mathrm{n}} \\
\vdots & \vdots & \ddots & \vdots \\
\mathrm{C}_{\mathrm{n} 1} & \mathrm{C}_{\mathrm{n} 2} & \cdots & 0
\end{array}\right]
$$

Step 2: Normalized initial direct-relation matrix 
The normalized initial direct-relation matrix $\mathrm{G}$ is calculated by normalizing the average matrix $C$ through Equations (2) and (3):

$$
\begin{gathered}
S=\max \left(\max _{1 \leq \mathrm{i} \leq \mathrm{n}} \sum_{j=1}^{\mathrm{n}} \mathrm{C}_{\mathrm{ij},} \max _{1 \leq \mathrm{j} \leq \mathrm{n}} \sum_{\mathrm{i}=1}^{\mathrm{n}} \mathrm{C}_{\mathrm{ij}}\right) \\
\mathrm{G}=\frac{\mathrm{C}}{\mathrm{S}}
\end{gathered}
$$

The sum of row $i$ in matrix $C, \sum_{j=1}^{n} C_{i j}$, means the total direct effect of cause $i$ on other causes, $\max _{1 \leq i \leq n} \sum_{j=1}^{n} C_{i j}$, means the highest total direct effect produces other causes. Analogously, $\max _{1 \leq \mathrm{j} \leq \mathrm{n}} \sum_{\mathrm{i}=1}^{\mathrm{n}} \mathrm{C}_{\mathrm{ij}}$ represents the maximum value the total direct effect receives from other causes. The positive scalar $S$ takes the larger of the two values, and the normalized initial direct-relation matrix $\mathrm{G}$ can be obtained by dividing each element of the original average matrix $C$ by $S$ [53]. The value of each element $G_{i j}$ of matrix $G$ is between 0 and 1 .

Based on the normalized direct-relation matrix $G$, the initial effect an element exerts and receives from another is determined [54]. Each element in matrix $G$ portrays a relationship among all of the elements in the system and can be converted into a visible impact-digraph-map [54]. For example (as shown in Figure 2), the experts are asked to evaluate only the direct effect. In the directed digraph graph, element a directly influences elements $\mathrm{b}$ and c; indirectly, it also affects first d, e, and f and, secondly, $g$ [54]. Therefore, the visible map based on the normalized direct-relation matrix $G$ helps to understand the structure of elements in the system.

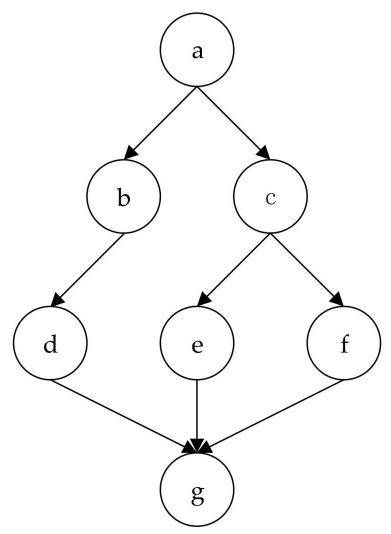

Figure 2. An example of direct graph.

Step 3: Total relation matrix

The power of the normalized initial direct-relation matrix $G, G^{m}$, which is called $\mathrm{m}$-indirect influence, can be used to indicate the effect of length $\mathrm{m}$ [53]. The direct influence of problems can be gradually diminished by $G^{2}, G^{3}, \ldots, G^{\infty}$, to guarantee convergent solutions to the matrix inversion [55]. For example, in Figure 2, the influence of element a on element $g$ is smaller than element a on element $d$, and again smaller than the influence exerted on element $b$ [54]. By using the infinite series, the full direct and indirect effects of each element can be illustrated. Therefore, the total relation matrix $\mathrm{T}$ can be obtained by summing up $G, G^{2}, G^{3}, \ldots, G^{\infty}$, as shown in Equation (4), where $I=$ an $n \times n$ identity matrix.

$$
\mathrm{T}=\sum_{\mathrm{n}=1}^{\infty} \mathrm{G}^{\mathrm{i}}=\mathrm{G}+\mathrm{G}^{2}+\ldots+\mathrm{G}^{\mathrm{n}}=\frac{\mathrm{G}\left(\mathrm{I}-\mathrm{G}^{\infty}\right)}{\mathrm{I}-\mathrm{G}}=\frac{\mathrm{G}}{\mathrm{I}-\mathrm{G}}=\mathrm{G}(\mathrm{I}-\mathrm{G})^{-1}
$$

Step 4: The influencing and influenced degrees

The row sums $\left(\mathrm{F}_{\mathrm{i}}\right)$ of the total relation matrix $\mathrm{T}$ means the overall direct and indirect influence dispatching from cause i to other causes. Analogously, if each column in the total relation matrix is added $\left(\mathrm{E}_{\mathrm{i}}\right)$, the overall direct and indirect influence that cause i receives 
from other causes can be obtained. In other words, $E_{i}$ represents the influenced degrees of cause i by other causes, whether direct or indirect.

$$
\begin{aligned}
& F_{i}=\sum_{j=1}^{n} t_{i j}(i=1,2, \ldots, n) \\
& E_{i}=\sum_{j=1}^{n} t_{j i}(i=1,2, \ldots, n)
\end{aligned}
$$

Step 5: The centrality and causality

Based on Equations (5) and (6), the centrality of dispute cause i and causality of cause $i$ are determined by using Equations (7) and (8):

$$
\begin{aligned}
& \mathrm{M}_{\mathrm{i}}=\mathrm{F}_{\mathrm{i}}+\mathrm{E}_{\mathrm{i}} \\
& \mathrm{N}_{\mathrm{i}}=\mathrm{F}_{\mathrm{i}}-\mathrm{E}_{\mathrm{i}}
\end{aligned}
$$

The sum $\left(\mathrm{F}_{\mathrm{i}}+\mathrm{E}_{\mathrm{i}}\right)$ represents the overall influence both exerted and received by the cause i. It indicates the degree of the importance that the cause i plays. The larger the value of $\mathrm{M}_{\mathrm{i}}\left(\mathrm{F}_{\mathrm{i}}+\mathrm{E}_{\mathrm{i}}\right)$ is, the more important cause $\mathrm{i}$ is among all of the dispute causes. Additionally, the difference value of $\left(F_{i}-E_{i}\right)$ determines the net effect that the cause $i$ contributes to the system. If the causality $\mathrm{N}_{\mathrm{i}}$ is a positive value, then cause i plays a causal role in triggering other causes. If $\mathrm{N}_{\mathrm{i}}$ is a negative value, then cause $\mathrm{i}$ is affected by other causes [54].

Step 6: Draw the cause-effect diagram

The total-relation matrix $\mathrm{T}$ provides information on how one cause influences another. Furthermore, the cause-effect diagram which explains the causal relationships among PPP dispute causes can be portrayed based on the total-relation matrix T. To keep the complexity and avoid over-complications when drawing the cause-effect diagram, an appropriate threshold value needs to be set to filter out negligible effects in matrix $\mathrm{T}$ [55]. Generally, the sum of the mean and standard deviation of the total-relation matrix $\mathrm{T}$ is established as the threshold [43].

Therefore, the centrality (M) is set as the abscissa and the causality $(\mathrm{N})$ is set as the ordinate, the cause-effect diagram can be acquired by mapping a Cartesian coordinate system with two quadrants. The positions of different dispute causes can be marked in the cause-effect diagram, which will be helpful to provide valuable insights for analyzing the complicated causal relationships of the PPP dispute causes.

\subsection{Data Source}

An empirical questionnaire was conducted to determine the relative importance and the interrelations among the PPP dispute causes (Table 2) under the guidance of the application steps of the DEMATEL method. The respondents were requested to rate the influencing degree of cause $C_{i}$ on $C_{j}$ within their jurisdiction with the standards of five-point Likert items $(0=$ no influence, $1=$ weak influence, $2=$ moderate influence, $3=$ relatively strong influence, and $4=$ strong influence). A total of 16 respondents with different perspectives of PPP projects from government departments (public sectors), former private investors, academic organizations, management consultancies, financiers, law firms, and so on agreed to take part in the study. All of them are experts or researchers who have hands-on experience in PPP projects to ensure the quality of data. They were investigated and interviewed via face-to-face meeting and/or email. Through the method introduced in the first step of Section 3.2, the evaluation scales assigned by experts were aggregated to form the original average matrix. The experts' profiles are shown in Table 3. 
Table 3. Profiles of the experts.

\begin{tabular}{|c|c|c|c|c|c|}
\hline \multirow{2}{*}{ No. } & \multirow{2}{*}{ Roles in PPP Projects } & \multirow{2}{*}{$\begin{array}{l}\text { Number of } \\
\text { Participates }\end{array}$} & \multicolumn{3}{|c|}{ Years of Experience } \\
\hline & & & $<10$ & 10-15 & $>15$ \\
\hline 1 & Central government & 2 & & 1 & 1 \\
\hline 2 & Local government & 3 & 1 & 1 & 1 \\
\hline 3 & Private sectors & 4 & 1 & 2 & 1 \\
\hline 4 & Consultant & 3 & & 2 & 1 \\
\hline 5 & Contractor & 2 & 1 & 1 & \\
\hline 6 & Designer & 1 & 1 & & \\
\hline 7 & Financier & 1 & 1 & & \\
\hline
\end{tabular}

According to Lindstrom [56], when analyzing the causes of specific problems, a small size of the data still dominated for further analysis. Meanwhile, similar studies have been conducted through the DEMATEL method to identify and analyze the relative importance of factors for a problem. For example, Zhang et al. [57] received 20 questionnaires, whereas Costa et al. [43] obtained 8 responses from Brazil and Italy. Therefore, the samples are considered satisfactory to draw meaningful conclusions because the 16 respondents are all knowledgeable and practiced on PPP.

\section{Result Analysis and Discussion}

\subsection{Results}

MATLAB (version 2015b), a high-performance programming language, was used in this study for calculating the models. According to the aforementioned design steps of DEMATEL, the calculation process is shown as follows:

Step 1: Original average matrix

Based on Equation (1), the original average matrix $C$ of the relations among PPP dispute causes from the respondents' opinions was calculated and presented in Table 4.

Table 4. Direct-relation matrix.

\begin{tabular}{|c|c|c|c|c|c|c|c|c|c|c|c|c|c|c|c|}
\hline & C1 & $\mathrm{C} 2$ & C3 & C4 & C5 & C6 & C7 & C8 & C9 & C10 & C11 & C12 & C13 & C14 & C15 \\
\hline $\mathrm{C} 1$ & 0.00 & 0.81 & 0.00 & 0.50 & 2.94 & 0.19 & 0.38 & 1.25 & 0.94 & 0.88 & 0.13 & 4.00 & 0.00 & 3.31 & 0.50 \\
\hline $\mathrm{C} 2$ & 3.25 & 0.00 & 4.00 & 4.00 & 4.00 & 4.00 & 3.06 & 2.94 & 3.44 & 0.13 & 3.06 & 2.19 & 3.13 & 2.75 & 4.00 \\
\hline $\mathrm{C} 3$ & 0.00 & 3.63 & 0.00 & 3.31 & 0.00 & 0.00 & 2.75 & 2.44 & 2.75 & 0.06 & 3.88 & 0.00 & 0.13 & 4.00 & 2.94 \\
\hline $\mathrm{C} 4$ & 0.31 & 1.81 & 0.00 & 0.00 & 1.00 & 2.88 & 0.00 & 3.19 & 0.06 & 0.13 & 3.44 & 0.25 & 0.13 & 4.00 & 3.38 \\
\hline C5 & 0.19 & 0.06 & 0.50 & 0.00 & 0.00 & 1.69 & 0.00 & 1.31 & 0.00 & 3.00 & 0.19 & 0.00 & 0.00 & 2.88 & 2.63 \\
\hline C6 & 4.00 & 0.75 & 2.44 & 3.88 & 1.69 & 0.00 & 3.69 & 0.88 & 0.00 & 0.19 & 1.69 & 3.06 & 0.00 & 3.69 & 3.50 \\
\hline C7 & 1.50 & 3.25 & 0.00 & 0.00 & 0.00 & 2.56 & 0.00 & 2.75 & 0.00 & 0.06 & 3.69 & 0.00 & 2.69 & 4.00 & 0.00 \\
\hline $\mathrm{C} 8$ & 4.00 & 0.00 & 0.00 & 0.19 & 0.00 & 0.00 & 0.00 & 0.00 & 1.06 & 0.00 & 0.00 & 3.94 & 0.00 & 4.00 & 3.69 \\
\hline C9 & 3.13 & 3.50 & 3.44 & 3.56 & 1.13 & 1.06 & 2.31 & 3.75 & 0.00 & 0.00 & 3.06 & 0.94 & 0.31 & 4.00 & 3.56 \\
\hline C10 & 2.94 & 3.44 & 3.81 & 3.38 & 0.75 & 0.38 & 3.94 & 0.38 & 0.00 & 0.00 & 0.38 & 2.88 & 0.00 & 3.19 & 3.31 \\
\hline C11 & 3.19 & 3.13 & 2.38 & 3.88 & 0.06 & 0.69 & 3.13 & 3.38 & 0.13 & 0.00 & 0.00 & 0.13 & 0.94 & 4.00 & 3.06 \\
\hline $\mathrm{C} 12$ & 0.00 & 0.13 & 0.00 & 0.00 & 0.00 & 0.00 & 0.00 & 3.19 & 0.25 & 0.00 & 0.00 & 0.00 & 0.00 & 4.00 & 0.13 \\
\hline C13 & 3.94 & 3.00 & 3.69 & 4.00 & 3.13 & 4.00 & 3.94 & 0.81 & 0.88 & 0.19 & 2.88 & 3.31 & 0.00 & 3.63 & 4.00 \\
\hline C14 & 2.38 & 0.94 & 0.00 & 2.81 & 0.00 & 0.00 & 3.06 & 3.88 & 2.31 & 0.00 & 0.00 & 2.81 & 0.00 & 0.00 & 0.00 \\
\hline C15 & 0.00 & 1.25 & 0.19 & 4.00 & 0.00 & 3.31 & 0.31 & 2.69 & 0.00 & 0.38 & 0.44 & 0.00 & 0.00 & 4.00 & 0.00 \\
\hline
\end{tabular}

Step 2: Normalized initial direct-relation matrix

As per the calculation methods of Equations (2) and (3), the normalized initial directrelation matrix $\mathrm{G}$ is obtained and shown in Table 5. 
Table 5. Normalized matrix.

\begin{tabular}{|c|c|c|c|c|c|c|c|c|c|c|c|c|c|c|c|}
\hline & C1 & C2 & C3 & C4 & C5 & C6 & C7 & C8 & C9 & C10 & C11 & $\mathrm{C} 12$ & C13 & C14 & C15 \\
\hline C1 & 0.00 & 0.02 & 0.00 & 0.01 & 0.07 & 0.00 & 0.01 & 0.03 & 0.02 & 0.02 & 0.00 & 0.09 & 0.00 & 0.08 & 0.01 \\
\hline $\mathrm{C} 2$ & 0.07 & 0.00 & 0.09 & 0.09 & 0.09 & 0.09 & 0.07 & 0.07 & 0.08 & 0.00 & 0.07 & 0.05 & 0.07 & 0.06 & 0.09 \\
\hline C3 & 0.00 & 0.08 & 0.00 & 0.08 & 0.00 & 0.00 & 0.06 & 0.06 & 0.06 & 0.00 & 0.09 & 0.00 & 0.00 & 0.09 & 0.07 \\
\hline C4 & 0.01 & 0.04 & 0.00 & 0.00 & 0.02 & 0.07 & 0.00 & 0.07 & 0.00 & 0.00 & 0.08 & 0.01 & 0.00 & 0.09 & 0.08 \\
\hline C5 & 0.00 & 0.00 & 0.01 & 0.00 & 0.00 & 0.04 & 0.00 & 0.03 & 0.00 & 0.07 & 0.00 & 0.00 & 0.00 & 0.07 & 0.06 \\
\hline C6 & 0.09 & 0.02 & 0.06 & 0.09 & 0.04 & 0.00 & 0.08 & 0.02 & 0.00 & 0.00 & 0.04 & 0.07 & 0.00 & 0.08 & 0.08 \\
\hline C7 & 0.03 & 0.07 & 0.00 & 0.00 & 0.00 & 0.06 & 0.00 & 0.06 & 0.00 & 0.00 & 0.08 & 0.00 & 0.06 & 0.09 & 0.00 \\
\hline C8 & 0.09 & 0.00 & 0.00 & 0.00 & 0.00 & 0.00 & 0.00 & 0.00 & 0.02 & 0.00 & 0.00 & 0.09 & 0.00 & 0.09 & 0.08 \\
\hline C9 & 0.07 & 0.08 & 0.08 & 0.08 & 0.03 & 0.02 & 0.05 & 0.09 & 0.00 & 0.00 & 0.07 & 0.02 & 0.01 & 0.09 & 0.08 \\
\hline C10 & 0.07 & 0.08 & 0.09 & 0.08 & 0.02 & 0.01 & 0.09 & 0.01 & 0.00 & 0.00 & 0.01 & 0.07 & 0.00 & 0.07 & 0.08 \\
\hline C11 & 0.07 & 0.07 & 0.05 & 0.09 & 0.00 & 0.02 & 0.07 & 0.08 & 0.00 & 0.00 & 0.00 & 0.00 & 0.02 & 0.09 & 0.07 \\
\hline C12 & 0.00 & 0.00 & 0.00 & 0.00 & 0.00 & 0.00 & 0.00 & 0.07 & 0.01 & 0.00 & 0.00 & 0.00 & 0.00 & 0.09 & 0.00 \\
\hline C13 & 0.09 & 0.07 & 0.08 & 0.09 & 0.07 & 0.09 & 0.09 & 0.02 & 0.02 & 0.00 & 0.07 & 0.08 & 0.00 & 0.08 & 0.09 \\
\hline C14 & 0.05 & 0.02 & 0.00 & 0.06 & 0.00 & 0.00 & 0.07 & 0.09 & 0.05 & 0.00 & 0.00 & 0.06 & 0.00 & 0.00 & 0.00 \\
\hline C15 & 0.00 & 0.03 & 0.00 & 0.09 & 0.00 & 0.08 & 0.01 & 0.06 & 0.00 & 0.01 & 0.01 & 0.00 & 0.00 & 0.09 & 0.00 \\
\hline
\end{tabular}

Step 3: Total relation matrix $\mathrm{T}$

According to Equation (4), the total relation matrix $\mathrm{T}$ is defined based on normalized initial matrix $\mathrm{G}$ and shown in Table 6 .

Table 6. Total relation matrix.

\begin{tabular}{|c|c|c|c|c|c|c|c|c|c|c|c|c|c|c|c|}
\hline & $\mathrm{C} 1$ & $\mathrm{C} 2$ & C3 & C4 & C5 & C6 & C7 & C8 & C9 & C10 & C11 & $\mathrm{C} 12$ & C13 & C14 & C15 \\
\hline C1 & 0.02 & 0.03 & 0.01 & 0.03 & 0.07 & 0.02 & 0.03 & 0.06 & 0.03 & 0.03 & 0.02 & 0.11 & 0.00 & 0.12 & 0.04 \\
\hline $\mathrm{C} 2$ & 0.15 & 0.07 & 0.13 & 0.18 & 0.13 & 0.15 & 0.14 & 0.17 & 0.11 & 0.02 & 0.14 & 0.12 & 0.09 & 0.22 & 0.18 \\
\hline C3 & 0.06 & 0.13 & 0.03 & 0.14 & 0.02 & 0.04 & 0.11 & 0.13 & 0.09 & 0.01 & 0.13 & 0.04 & 0.02 & 0.18 & 0.13 \\
\hline $\mathrm{C} 4$ & 0.05 & 0.07 & 0.02 & 0.05 & 0.04 & 0.09 & 0.04 & 0.12 & 0.02 & 0.01 & 0.10 & 0.04 & 0.01 & 0.16 & 0.12 \\
\hline C5 & 0.03 & 0.02 & 0.02 & 0.03 & 0.01 & 0.05 & 0.02 & 0.06 & 0.01 & 0.07 & 0.02 & 0.02 & 0.00 & 0.10 & 0.08 \\
\hline C6 & 0.13 & 0.06 & 0.07 & 0.14 & 0.06 & 0.04 & 0.12 & 0.09 & 0.02 & 0.01 & 0.08 & 0.11 & 0.01 & 0.18 & 0.13 \\
\hline C7 & 0.09 & 0.11 & 0.03 & 0.06 & 0.03 & 0.09 & 0.05 & 0.12 & 0.03 & 0.01 & 0.11 & 0.05 & 0.07 & 0.16 & 0.05 \\
\hline C8 & 0.11 & 0.02 & 0.01 & 0.03 & 0.01 & 0.01 & 0.02 & 0.04 & 0.04 & 0.00 & 0.01 & 0.11 & 0.00 & 0.13 & 0.10 \\
\hline C9 & 0.13 & 0.13 & 0.11 & 0.15 & 0.06 & 0.07 & 0.10 & 0.17 & 0.04 & 0.01 & 0.12 & 0.08 & 0.03 & 0.21 & 0.15 \\
\hline C10 & 0.11 & 0.12 & 0.11 & 0.13 & 0.04 & 0.05 & 0.13 & 0.08 & 0.03 & 0.01 & 0.06 & 0.11 & 0.02 & 0.17 & 0.13 \\
\hline C11 & 0.12 & 0.11 & 0.08 & 0.15 & 0.03 & 0.06 & 0.11 & 0.15 & 0.03 & 0.01 & 0.04 & 0.05 & 0.04 & 0.19 & 0.13 \\
\hline C12 & 0.02 & 0.01 & 0.00 & 0.01 & 0.00 & 0.00 & 0.01 & 0.09 & 0.01 & 0.00 & 0.00 & 0.02 & 0.00 & 0.11 & 0.01 \\
\hline C13 & 0.16 & 0.13 & 0.12 & 0.18 & 0.11 & 0.15 & 0.15 & 0.12 & 0.06 & 0.02 & 0.13 & 0.14 & 0.02 & 0.22 & 0.17 \\
\hline C14 & 0.09 & 0.05 & 0.01 & 0.09 & 0.02 & 0.02 & 0.09 & 0.13 & 0.07 & 0.00 & 0.03 & 0.09 & 0.01 & 0.06 & 0.03 \\
\hline C15 & 0.04 & 0.05 & 0.02 & 0.12 & 0.01 & 0.10 & 0.04 & 0.10 & 0.02 & 0.01 & 0.03 & 0.03 & 0.01 & 0.14 & 0.04 \\
\hline
\end{tabular}

Step 4: The influencing and influenced degrees

Within the total-relation matrix $\mathrm{T}$, the influencing degree (F) and influenced degree (E) can be separately obtained through Equations (5) and (6), as shown in Table 7.

Step 5: The centrality and causality

The centrality $(F+E)$ and causality $(F-E)$ can be directly obtained based on the value of $F$ and $E$. The results are arranged in Table 7 . The centrality $(F+E)$ reflects the prominence or importance of the influences of the dispute causes in the complicated system [58]. Meanwhile, the dispute sources are also categorized into a reason group and a result group accordingly based on the values of causality $(\mathrm{F}-\mathrm{E})$.

Step 6: Set a threshold and the cause-effect diagram

To explain the relationship among the PPP dispute causes more clearly, a cause-effect diagram is necessary to show adequate information for dispute prevention and resolution. The threshold value 0.13 was obtained by adding one standard deviation to the mean of the total matrix T (Table 6). Values in the total matrix T higher than the threshold value (0.13) are shown in bold in Table 6. For example, the value from the second row and the fourth column is 0.18 , which means that C2 will affect C4. 
Table 7. The degree of centrality and causality.

\begin{tabular}{ccccccc}
\hline & $\mathbf{F}$ & $\mathbf{E}$ & Centrality $=\mathbf{F}+\mathbf{E}$ & Rank & Causality $=\mathbf{F}-\mathbf{E}$ & Category \\
\hline C1 & 0.64 & 1.31 & 1.95 & 12 & -0.68 & Result \\
C2 & 2.01 & 1.09 & 3.10 & 2 & 0.92 & Reason \\
C3 & 1.27 & 0.78 & 2.05 & 11 & 0.49 & Reason \\
C4 & 0.94 & 1.50 & 2.44 & 3 & -0.56 & Result \\
C5 & 0.56 & 0.64 & 1.20 & 15 & -0.08 & Result \\
C6 & 1.24 & 0.94 & 2.18 & 9 & 0.30 & Reason \\
C7 & 1.05 & 1.15 & 2.19 & 8 & -0.10 & Result \\
C8 & 0.65 & 1.64 & 2.28 & 5 & -0.99 & Result \\
C9 & 1.55 & 0.61 & 2.16 & 10 & 0.93 & Reason \\
C10 & 1.30 & 0.21 & 1.51 & 13 & 1.09 & Reason \\
C11 & 1.29 & 1.00 & 2.30 & 4 & 0.29 & Reason \\
C12 & 0.31 & 1.14 & 1.45 & 14 & -0.83 & Result \\
C13 & 1.86 & 0.35 & 2.21 & 7 & 1.52 & Reason \\
C14 & 0.78 & 2.35 & 3.13 & 1 & -1.57 & Result \\
C15 & 0.76 & 1.49 & 2.25 & 6 & -0.73 & Result \\
\hline
\end{tabular}

Finally, the prominence and cause-effect diagram is drawn in Figure 3. The lines with arrows mean the direction of the relationships among causes have matrix values higher than the threshold value (0.13). The dotted lines with arrows indicate the dispute sources of the result category influencing others.

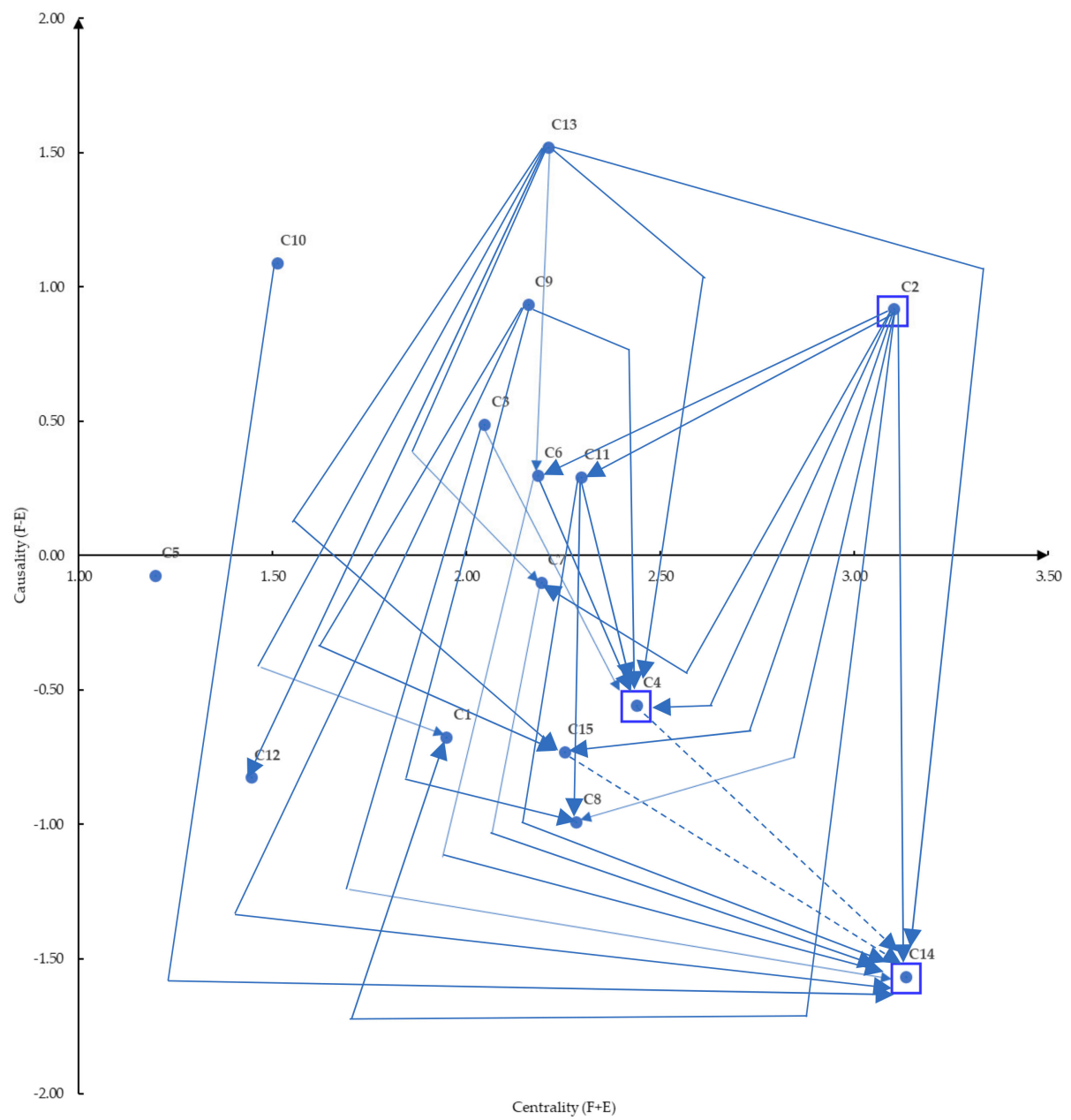

Figure 3. Prominence and cause-effect diagram. 


\subsection{Discussion}

The influencing and influenced degrees, centrality, causality (Table 7), and the causeeffect diagram (Figure 2) provide a comprehensive view of analyzing the importance of PPP dispute causes from different perspectives. First, previous studies have demonstrated that the centrality $(\mathrm{F}+\mathrm{E})$ reflects the importance of a factor in the system [41,46]. Further, in the first quadrant, the dispute causes with positive values of causality $(\mathrm{F}-\mathrm{E})$ belong to the reason group; whereas in the fourth quadrant, the negative values $(F-E)$ signify that the causes are regarded as the result group $[23,57]$.

Considering there are a total number of 15 dispute causes extracted in this study, only the top three causes from different perspectives were selected to represent the decisive causes. This approach is consistent with other similar studies $[44,59,60]$.

\subsubsection{Dispute Sources of The Reason Category}

As shown in Figure 2, in the first quadrant of the coordinate plane, the causality of $\mathrm{C} 2, \mathrm{C} 3, \mathrm{C} 6, \mathrm{C} 9, \mathrm{C} 10, \mathrm{C} 11$, and $\mathrm{C} 13$ is higher than zero, which indicates that these potential dispute causes are extremely possible to influence the occurrence of other dispute causes, then the combination of them leads to a dispute. In Figure 2, considering the rankings of the influencing degrees (F), the top three causes are C2 (lack of expertise and experience), C13 (inadequate investigation and preparation), and C9 (unexpected changes), which influences eight, seven, and four other causes, respectively.

C2 (lack of expertise and experience) influences the biggest number of other causes. The results are not surprising because several studies in China have demonstrated that the lack of adequate knowledge, skills, and experience in PPPs often leads to many problems, even disputes [13,61]. In China, many local government authorities do not have enough experience and they also fail to introduce some professional talents to provide service and guidance for the decision-making process. As a consequence, it is very possible for governments to make wrong decisions, such as excessive or unrealistic guarantees, ambiguous contract design, and inaccurate demand forecasts. Further, these decisions may become the fuse of disputes. For instance, to attract the private sector's investment, a high financial subsidy tends to be promised by the government. Once the revenues are not up to the expectations, the governments are forced to provide huge subsidies according to the contract [34]; whereas insufficient financing capacity will lead to a repudiation of contract and eventually result in lengthy disputes [60].

The influencing degrees (F) of C13 (inadequate investigation and preparation) is ranked second with scores of 1.86 . Throughout the life cycle of PPP projects, preliminary investigation plays a determining role in a successful PPP project because it directly relates to entire steps in PPP project development and implementation. Inadequate preparation often includes inadequate site investigation, insufficient market research, an unreasonable compensation plan for displaced persons, and so on $[13,34,62]$. For example, if the project is located in areas with sensitive targets, such as ecological resources, historical and cultural sites, or large communities, for one thing, it is impossible to obtain the official approvals; for another, nearby residents will adamantly resist the construction of PPP projects, especially the sewage treatment plant and waste treatment plant, because they believe their health and asset values will be threatened. The cases of the Mianyang Underground Space Development Project and Dengfeng Ludian Sewage Treatment Plant in Table 1 explained the formation of a dispute due to inadequate site investigation.

The influencing degree (F) of $\mathrm{C} 9$ (unexpected changes) is ranked third with scores of 1.55. Previous studies have also proved that the unexpected changes in China, such as law and regulatory changes, tariff changes, market demand changes, nationalization, and so forth, is one of the primary causes of PPP dispute [18,34]. These changes would have a serious impact on project revenue, award process, and financing. On the one hand, the juristic system of PPP development and implementation is still immature in China. At present, there is no national PPP law with absolute authority in China, which cannot provide a good investment environment for private sectors [34]. With the implementation of the 
PPPs, more and more new problems will appear, which will be followed by the adjustment of laws and regulations. A common example is the cancelation of excessive guarantees. On the other hand, with Chinese rapid economic development, both governments and private sectors do not always form accurate forecasts about urban development due to bounded rationality and information asymmetry. Therefore, unexpected changes are inevitable and have hidden hazards on PPP implementation.

\subsubsection{Dispute Sources of The Result Category}

In the fourth quadrant of the cause-effect diagram (Figure 2), the influencing degrees of $\mathrm{C} 1, \mathrm{C} 4, \mathrm{C} 5, \mathrm{C} 7, \mathrm{C} 8, \mathrm{C} 12, \mathrm{C} 14$, and $\mathrm{C} 15$ are lower than zero, demonstrating that the occurrence of these causes is very susceptible to the causes in the reason category. Among those, C14 (repudiation of contract) and C4 (unreasonable risk allocation) are the most prominent.

C14 (repudiation of contract) is most impacted by other causes, indicating that it can be considered the main consequence. For example, the absence of enough experience and knowledge (C2) often leads to a skimpy understanding of the contractual duties and obligations [30,61]. Eventually, the improperly performing of contracts lead to a breach of contracts $[13,34]$. The collaborative relationship between public and private sectors would be destroyed or seriously damaged by the repudiation of contract. Whereas the relationship proved to be the critical factor for the success of a PPP project [63]. For governments, the common repudiation of the contract includes payment default, construction of competitive projects, absence of supportive infrastructure, and delays in expropriation [18,32]. For the private sector, unqualified public service and capital chain rupture occur more frequently.

C4 (unreasonable risk allocation) is influenced by the second biggest number of other causes. The prevalent principle of risk allocation is that risks should be allocated to the party best able to manage them and at the least cost [64]. The contract theory enforces the idea that an unfair risk allocation agreement tends to be disputed more often [18]. For instance, Ke et al. [26] conducted a questionnaire survey and the results showed that the risk of "project approvals and permits" tends to be assigned to the public authority. In the case of Yichang Waste-to-Energy Power Plant (Table 1), the contract stipulated that the private partner is responsible for all the approval procedures of the project. Obviously, it is unfair because the approval risk is supposed to be the responsibility of the government. Undoubtedly, if both parties to the contract are inexperienced, it is easy to make an incorrect assessment of their ability to deal with the risk. Analogously, unreliable feasibility studies (C6), inadequate investigation and preparation (C13) and poor financial affordability (C11) can also cause unreasonable/unfair risk allocation.

\subsubsection{Analysis of Centrality}

From Table 7 and Figure 2, the top three causes are C14 (repudiation of contract), C2 (lack of expertise and experience), and C4 (unreasonable risk allocation) in terms of centrality $(\mathrm{F}+\mathrm{E})$. The more value of centrality, the more decisive the cause is because centrality depicts the prominence or importance degree of each cause [65]. Considering the overall influencing degrees $(\mathrm{F})$ and influenced degrees $(\mathrm{E})$, these three causes have the greatest impact on PPP disputes in China. Thus, the findings from the DEMATEL method will be helpful to provide effective strategies to avoid or reduce the occurrence of PPP disputes.

\section{Recommendations}

Based on the major findings of this study, some significant strategies or implications are provided in Table 8 for both the governments and private partners to prevent or minimize the occurrence of disputes in PPP agreements. 
Table 8. The results and recommendations.

\begin{tabular}{|c|c|c|c|}
\hline \multicolumn{2}{|c|}{ Decisive Causes } & \multicolumn{2}{|c|}{ Strategies or Implications } \\
\hline Category & Symbol & For Governments & For Private Parties \\
\hline & $\begin{array}{l}\text { C2-lack of expertise } \\
\text { and experience }\end{array}$ & $\begin{array}{l}\text { (1) The government should strengthen } \\
\text { the study of project site selection, } \\
\text { demand forecasting, feasibility studies, } \\
\text { and legal knowledge (Contract Law, } \\
\text { Tenders and Bids Law, etc.). } \\
\text { (2) A professional PPP consulting team } \\
\text { needs to be hired to provide reliable } \\
\text { information for decision making. }\end{array}$ & $\begin{array}{l}\text { (1) The private sector should enhance } \\
\text { its knowledge of contract design, } \\
\text { operation and maintenance } \\
\text { management, risk management, etc. } \\
\text { (2) The private sector should learn } \\
\text { from previous litigation cases, it must } \\
\text { defend its rights legally to avoid } \\
\text { illegal or improper operation } \\
\text { behaviors. }\end{array}$ \\
\hline
\end{tabular}

(1) The promulgation of national PPP law is needed to provide a unified and

Reason category

\section{C9-unexpected} changes stable principle for the implementation of PPPs. Thus, it can contribute to reducing the impact of regulation changes on the project.

(2) A dynamic adjustment mechanism should be stipulated in PPP contracts to respond to unexpected changes. In addition, the trigger conditions for adjustment and adjustment methods should also be established.

C13-inadequate investigation and preparation
The establishment of a lifelong liability mechanism for government officials will help improve the investigation and preparation reliability and decrease decision errors.
Considering huge investments are required in PPP projects, apart from financing support from the government, to prevent financing failure and ensure the sufficient capital supply, it is necessary to communicate with financial institutions in the preparation stage to understand the financial ability and financial difficulty of the project.

The proper forms of public guarantees can be selected to ensure a more reasonable risk allocation scheme. For example, to mitigate the revenue risk of the private sector, the minimum revenue guarantee (MRG) or exclusive guarantee can be adopted [66]. Meanwhile, the government must avoid excessive guarantees.

Result category

(1) The credit ratings by rating agencies are required to improve the local government's reputation (the spirit of contract) and then reduce the

C14-repudiation of contract
(2) If the default cost is greatly increased in the contract, the government does not enjoy the real possibility to breach the concessions.
The private sector should conduct detailed preliminary research to draw reliable conclusions about its risk-bearing capacity. The promises beyond its risk-bearing capacity cannot be made to win the bid.

(1) To prevent default, a supervision mechanism for the private sector during the project lifecycle should be established. For example, to prevent financing failure, the government should screen for bidders with strong financial strengths in the tender process.

(2) To prompt the private investors to provide satisfactory products or services, incentive and punishment mechanisms should be established.

\section{Conclusions}

This paper recognized the specific causes of disputes in PPPs by means of the multicase study. Through a deep analysis of the document from the judgment, 15 causes were extracted and illustrated. The DEMATEL method was used to reveal the prominence and causal relationship among these causes. Experts with hands-on experience in PPP projects were invited to assign scores to evaluate the direct influence among different PPP dispute causes. By using the DEMATEL technique, the 15 causes were divided into the 
reason and result groups. Results showed that the top three dispute sources in the reason category are lack of expertise and experience, inadequate investigation and preparation, and unexpected changes. Meanwhile, the most influenced dispute sources in the result category are the repudiation of contract and unreasonable risk allocation. Considering the overall reason and result effect of each cause, the PPP dispute in China is mainly caused by the repudiation of contract, lack of expertise and experience, and unreasonable risk allocation.

The findings are not surprising because many local governments in China do not have enough in-depth knowledge and skill in PPP practices; therefore, incorrect decisions, unfair risk-sharing schemes, and unrealistic promises are often made by the governments, which result in the breach of contracts. To minimize dispute occurrence, both government and private partners need to strictly obey the contract and fulfill their duties and obligations. For the public sector, the establishment of a lifelong liability mechanism and the raised default cost in the contract will contribute to reducing the default. For the private sector, incentive and punishment mechanisms are proposed to avoid improper operation. Further, both the public and private sectors should conduct a detailed risk assessment and draw a reasonable risk allocation by mutual consent.

In summary, this study contributes to significant information on PPP disputes. First, it explores the potential sources of PPP disputes in China based on the actual litigation cases. This set of causes enriches the researches relevant to PPP disputes. Second, the DEMATEL method is an efficient technique to reveal the prominence and causal relationship among dispute causes. Finally, the proposed recommendations can help both the public and private sectors to prompt effective dispute-avoiding strategies before signing PPP agreements. Although this study reveals the specific dispute causes using litigation cases in the Chinese context, the outputs still provide adequate theoretical guidance for understanding the possible sources of disputes in PPPs. The research results can be used for the hypothesis formulation of empirical studies in the future.

However, this study is subject to several limitations. First, most PPP projects in China are still in the preparation, procurement, or construction stage, they have not yet entered the period of a large-scale outbreak of disputes. With the gradual increase in the number of dispute cases, potential research about PPP disputes in a particular industry or a particular phase would be worthwhile. Second, the list of dispute sources is not exhaustive because few studies have investigated the root causes of disputes in PPPs. It is therefore suggested that the current list of dispute causes need to be enhanced in the future. Third, although the interviewees with rich experience in PPP projects were invited to ensure the quality of data, there is still a factor of human subjective influence on the results of the experiment. Future research that involves more objective cases or data may provide a more scientific understanding of PPP disputes.

Author Contributions: Conceptualization, X.Z. and Y.L.; Data curation, X.Z., Y.L., R.S.; Formal analysis, X.Z.; Investigation, X.Z., R.S., J.T.; Methodology, X.Z., R.S., J.T.; Software, Q.Y.; Writing—original draft preparation, X.Z.; Writing—review and editing, X.Z., R.S. and J.T.; Project administration, X.Z. and Y.L.; Funding acquisition, Y.L. All authors have read and agreed to the published version of the manuscript.

Funding: This research was funded by National Natural Science Foundation of China, grant number 71841022 .

Institutional Review Board Statement: Not applicable.

Informed Consent Statement: Not applicable.

Data Availability Statement: Not applicable.

Conflicts of Interest: All the authors have no conflict of interests. 


\section{References}

1. Carrillo, P.; Robinson, H.; Foale, P.; Anumba, C.; Bouchlaghem, D. Participation, barriers, and opportunities in PFI: The United Kingdom experience. J. Manag. Eng. 2008, 24, 138-145. [CrossRef]

2. Ismail, S. Critical success factors of public private partnership (PPP) implementation in Malaysia. Asia Pac. J. Manag. 2013, 5, 6-19. [CrossRef]

3. Dansoh, A.; Frimpong, S.; Ampratwum, G.; Oppong, G.D.; Osei-Kyei, R. Exploring the role of traditional authorities in managing the public as stakeholders on PPP projects: A case study. Int. J. Proj. Manag. 2020, 20, 628-641. [CrossRef]

4. Osei-Kyei, R.; Chan, A.P. Review of studies on the Critical Success Factors for Public-Private Partnership (PPP) projects from 1990 to 2013. Int. J. Proj. Manag. 2015, 33, 1335-1346. [CrossRef]

5. Bing, L.; Akintoye, A.; Edwards, P.J.; Hardcastle, C. The allocation of risk in PPP/PFI construction projects in the UK. Int. J. Proj. Manag. 2005, 23, 25-35. [CrossRef]

6. KPMG. PPP Procurement: Review of Barriers to Competition and Efficiency in the Procurement of PPP Projects. Available online: http:/ / www.kpmg.com/NZ (accessed on 6 December 2021).

7. $\mathrm{Mu}, \mathrm{R} . ;$ Geogr. 2011, 19, 794-806. [CrossRef]

8. Zhang, S.; Gao, Y.; Feng, Z.; Sun, W. PPP application in infrastructure development in China: Institutional analysis and implications. Int. J. Proj. Manag. 2015, 33, 497-509. [CrossRef]

9. Wang, X.; Chen, Y.; Liu, B.; Shen, Y.; Sun, H. A total factor productivity measure for the construction industry and analysis of its spatial difference: A case study in China. Constr. Manag. Econ. 2013, 31, 1059-1071. [CrossRef]

10. Chen, C.; Doloi, H. BOT application in China: Driving and impeding factors. Int. J. Proj. Manag. 2008, 26, 388-398. [CrossRef]

11. China Public Private Partnerships Center (CCPPC). National PPP Information Platform. Available online: https://www.cpppc. org:8082/inforpublic/homepage.html\#/ projectPublic (accessed on 1 October 2021).

12. Chan, A.P.C.; Lam, P.T.I.; Wen, Y. Cross-sectional analysis of critical risk factors for PPP water projects in China. J. Infrastruct. Syst. 2015, 21, 04014031. [CrossRef]

13. Osei-Kyei, R.; Chan, A.P.C.; Yu, Y.; Chen, C.; Dansoh, A. Root causes of conflict and conflict resolution mechanisms in publicprivate partnerships: Comparative study between Ghana and China. Cities 2019, 87, 185-195. [CrossRef]

14. Osei-Kyei, R.; Chan, A.P.C. Developing transport infrastructure in Sub-Saharan Africa through public-private partnerships: Policy practice and implications. Transp. Rev. 2016, 36, 170-186. [CrossRef]

15. Grimsey, D.; Lewis, M.K. Evaluating the risks of public private partnerships for infrastructure projects. Int. J. Proj. Manag. 2002, 20, 107-118. [CrossRef]

16. Zheng, J.; Roehrich, J.K.; Lewis, M.A. The dynamics of contractual and relational governance: Evidence from long-term public-private procurement arrangements. J. Purch. Supply Manag. 2008, 14, 43-54. [CrossRef]

17. China Judgements Online. Available online: http://wenshu.court.gov.cn/ (accessed on 1 October 2021).

18. Zheng, X.; Liu, Y.; Jiang, J.; Thomas, L.M.; Su, N. Predicting the litigation outcome of PPP project disputes between public authority and private partner using an ensemble model. J. Bus. Econ. Manag. 2021, 22, 320-345. [CrossRef]

19. Lin, C.W.; Chen, S.H.; Tzeng, G.H. Constructing a cognition map of alternative fuel vehicles using the DEMATEL method. J. Multi-Criteria Decis. Anal. 2009, 16, 5-19. [CrossRef]

20. Echternach, M.; Pellerin, R.; Joblot, L. Litigation management process in construction industry. Procedia Comput. Sci. 2021, 181, 678-684. [CrossRef]

21. Cheung, S.O.; Suen, H.C.H.; Lam, T.I. Fundamentals of alternative dispute resolution processes in construction. J. Constr. Eng. Manag. 2002, 128, 409-417. [CrossRef]

22. Haugen, T.; Singh, A. Dispute resolution strategy selection. J. Leg. Aff. Disput. Resolut. Eng. Constr. 2015, 7, 05014004. [CrossRef]

23. Zhang, X.Q.; Xiong, W. Renegotiation and early-termination in public private partnership. Int. J. Archit. Eng. Constr. 2015, 4 , 204-213. [CrossRef]

24. Wang, S.Q.; Tiong, R.L.K.; Ting, S.K.; Ashley, D. Evaluation and management of foreign exchange and revenue risks in China's BOT projects. Constr. Manag. Econ. 2000, 18, 197-207. [CrossRef]

25. Wang, S.Q.; Tiong, R.L.K.; Ting, S.K.; Ashley, D. Evaluation and management of political risks in China's BOT projects. J. Constr. Eng. Manag. 2000, 126, 242-250. [CrossRef]

26. Ke, Y.J.; Wang, S.Q.; Chan, A.P.C. Risk allocation in public-private partnership infrastructure projects: Comparative study. J. Infrastruct. Syst. 2010, 16, 343-351. [CrossRef]

27. Cheung, E.; Chan, A.P.C. Risk factors of public-private partnership projects in China: Comparison between the water, power, and transportation sectors. J. Urban Plan. Dev. 2011, 137, 409-415. [CrossRef]

28. Song, J.; Song, D.; Zhang, X.; Sun, Y. Risk identification for PPP waste-to-energy incineration projects in China. Energy Policy 2013, 61, 953-962. [CrossRef]

29. Xu, Y.; Chan, A.P.C.; Xia, B.; Qian, Q.K.; Liu, Y.; Peng, Y. Critical risk factors affecting the implementation of PPP waste-to-energy projects in China. Appl. Energy 2015, 158, 403-411. [CrossRef]

30. Chan, A.P.C.; Lam, P.T.I.; Chan, D.W.M.; Cheung, E.; Ke, Y. Potential obstacles to successful implementation of public-private partnerships in Beijing and the Hong Kong special administrative region. J. Manag. Eng. 2010, 26, 30-40. [CrossRef] 
31. Chan, A.P.C.; Lam, P.T.I.; Chan, D.W.M.; Cheung, E.; Ke, Y. Critical success factors for PPPs in infrastructure developments: Chinese perspective. J. Constr. Eng. Manag. 2010, 136, 484-494. [CrossRef]

32. Cruz, C.O.; Marques, R.C. Exogenous determinants for renegotiating public infrastructure concessions: Evidence from Portugal. J. Constr. Eng. Manag. 2013, 139, 1082-1090. [CrossRef]

33. Cruz, C.O.; Marques, R.C. Endogenous determinants for renegotiating concessions: Evidence from local infrastructure. Local Gov. Stud. 2013, 39, 352-374. [CrossRef]

34. Song, J.; Hu, Y.; Feng, Z. Factors influencing early termination of PPP projects in China. J. Manag. Eng. 2018, $34,05017008$. [CrossRef]

35. Gabus, A.; Fontela, E. World Problems: An Invitation to Further Thought within the Framework of DEMATEL; Battelle Geneva Research Centre: Geneva, Switzerland, 1972.

36. Lin, Y.; Tseng, M.L.; Chen, C.C.; Chiu, A.S. Positioning strategic competitiveness of green business innovation capabilities using hybrid method. Expert Syst. Appl. 2011, 38, 1839-1849. [CrossRef]

37. Huang, C.Y.; Tzeng, G.H.; Chen, Y.T.; Chen, H. Performance evaluation of leading fabless integrated circuit design houses by using a multiple objective programming based data envelopment analysis approach. Int. J. Innov. Comput. Inf. Control 2012, 8 , 5899-5916.

38. Sofiyabadi, J.; Movahedi, M.; Noori Nasab, S. Strategic orientation in evaluation of supply chain activities. Manag. Sci. Lett. 2012, 2, 1785-1794. [CrossRef]

39. Chang, B.; Chang, C.W.; Wu, C.H. Fuzzy DEMATEL method for developing supplier selection criteria. Expert Syst. Appl. 2011, 38, 1850-1858. [CrossRef]

40. Chileshe, N.; Rameezdeen, R.; Hosseini, M.R. Drivers for adopting reverse logistics in the construction industry: A qualitative study. Eng. Constr. Archit. Manag. 2016, 23, 134-157. [CrossRef]

41. Hiete, M.; Kühlen, A.; Schultmann, F. Analysing the interdependencies between the criteria of sustainable building rating systems. Constr. Manag. Econ. 2011, 29, 323-328. [CrossRef]

42. Hsu, C.W.; Kuo, T.C.; Chen, S.H.; Hu, A.H. Using DEMATEL to develop a carbon management model of supplier selection in green supply chain management. J. Clean. Prod. 2013, 56, 164-172. [CrossRef]

43. Costa, F.; Denis Granja, A.; Fregola, A.; Picchi, F.; Portioli Staudacher, A. Understanding relative importance of barriers to improving the customer-supplier relationship within construction supply chains using DEMATEL technique. J. Manag. Eng. 2019, 35, 04019002. [CrossRef]

44. Dwijendra, N.K.A.; Akhmadeev, R.; Tumanov, D.; Kosov, M.; Shoar, S.; Banaitis, A. Modeling social impacts of high-rise residential buildings during the post-occupancy phase using DEMATEL method: A case study. Buildings 2021, 11, 504. [CrossRef]

45. Semple, C.; Hartman, F.T.; Jergeas, G. Construction claims and disputes: Causes and cost/time overruns. J. Constr. Eng. Manag. 1994, 120, 785-795. [CrossRef]

46. Koh, C.P. The Causes of Construction Dispute on Client Organizations. Ph.D. Thesis, Universiti Teknologi Malaysia, Johor Bahru, Malaysia, 2005.

47. Sambasivan, M.; Soon, Y.W. Causes and effects of delays in Malaysian construction industry. Int. J. Proj. Manag. 2007, 25, 517-526. [CrossRef]

48. Rauzana, A. Causes of conflicts and disputes in construction projects. J. Mech. Civ. Eng. 2016, 13, 44-48. [CrossRef]

49. El-Sayegh, S.; Ahmad, I.; Aljanabi, M.; Herzallah, R.; Metry, S.; El-Ashwal, O. Construction disputes in the UAE: Causes and resolution methods. Buildings 2020, 10, 171. [CrossRef]

50. Chen, C. Can the pilot BOT project provide a template for future projects? A case study of the Chengdu No. 6 Water Plant B Project. Int. J. Proj. Manag. 2009, 27, 573-583. [CrossRef]

51. Martins, A.C.; Marques, R.C.; Cruz, C.O. Public-private partnerships for wind power generation: The Portuguese case. Energy Policy 2011, 39, 94-104. [CrossRef]

52. Chen, C. Using DEMATEL method for medical tourism development in Taiwan. Am. J. Tour. Res. 2012, 1, 26-32.

53. Lee, H.S.; Tzeng, G.H.; Yeih, W.; Wang, Y.J.; Yang, S.H. Revised DEMATEL: Resolving the infeasibility of DEMATEL. Appl. Math. Model. 2013, 37, 6746-6757. [CrossRef]

54. Tzeng, G.H.; Chiang, C.H.; Li, C.W. Evaluating intertwined effects in e-learning programs: A novel hybrid MCDM model based on factor analysis and DEMATEL. Expert Syst. Appl. 2007, 32, 1028-1044. [CrossRef]

55. Li, C.W.; Tzeng, G.H. Identification of a threshold value for the DEMATEL method using the maximum mean de-entropy algorithm to find critical services provided by a semiconductor intellectual property mall. Expert Syst. Appl. 2009, 36, 9891-9898. [CrossRef]

56. Lindstrom, M. Small Data: The Tiny Clues That Uncover Huge Trends; Martins' Press: New York, NY, USA, 2016.

57. Zhang, Y.; Song, Y. Identification of food safety risk factors based on intelligence flow and DEMATEL-ISM (DEcision-MAking Trial and Evaluation Laboratory and Interpretative Structural Modeling). DYNA-Ing. Ind. 2020, 95, 418-424. [CrossRef]

58. Zhou, D.; Zhang, L. Establishing hierarchy structure in complex systems based on the integration of DEMATEL and ISM. J. Manag. Sci. China 2008, 11, 20-26.

59. Zou, P.X.W.; Zhang, G.; Wang, J. Understanding the key risks in construction projects in China. Int. J. Proj. Manag. 2007, 25, 601-614. [CrossRef] 
60. Ke, Y.; Wang, S.; Chan, A.P.; Cheung, E. Understanding the risks in China's PPP projects: Ranking of their probability and consequence. Eng. Constr. Archit. Manag. 2011, 18, 481-496. [CrossRef]

61. Wang, S.Q.; Ke, Y.J.; Xie, J. Public Private Partnership Implementation in China. In Taking Stock of PPP and PFI Around the World; Winch, G.M., Onishi, M., Schmidt, S., Eds.; The Association of Chartered Certified Accountants (ACCA): London, UK, 2012; pp. 29-36.

62. Kumaraswamy, M.M. Conflicts, claims and disputes in construction. Eng. Constr. Archit. Manag. 1997, 4, 95-111. [CrossRef]

63. Zou, W.; Kumaraswamy, M.; Chung, J.; Wong, J. Identifying the critical success factors for relationship management in PPP projects. Int. J. Proj. Manag. 2014, 32, 265-274. [CrossRef]

64. Cooper, D.F.; Grey, S.; Raymond, G.; Walker, P. Project Risk Management Guidelines: Managing Risk in Large Projects and Complex Procurements; Wiley: Chichester, UK, 2005.

65. Li, J.; Wu, C.H.; Chen, C.W.; Huang, Y.F.; Lin, C.T. Apply fuzzy DEMATEL to explore the decisive factors of the auto lighting aftermarket industry in Taiwan. Mathematics 2020, 8, 1187. [CrossRef]

66. Pellegrino, R. Effects of public supports for mitigating revenue risk in Public-Private Partnership projects: Model to choose among support alternatives. J. Constr. Eng. Manag. 2021, 147, 04021167. [CrossRef] 